\title{
ANALISIS PRICE TO BOOK VALUE RATIO MELALUI NET PROFIT MAR- GIN, RETURN ON ASSET, AND RETURN ON EQUITY
}

\author{
ADI SANTOSO (Santosoadi58@gmail.com)
}

Fakultas Ekonomi Universitas Muhammadiyah Ponorogo

\begin{abstract}
A B S T R A C T
This study aimed to determine the effect of Net Profit Margin, Return on Equity and Return on Assets of the Price to Book Value. This study uses secondary data obtained from the banks financial statements derived from the Indonesian Capital Market Directory (ICMD). The number of overall study sample there were 19 banks. The results found that the NPM and ROE PBV no significant effect. While ROA PBV positive effect. Contribution of all the variables classified, all the independent variables only able to give effect to the PBV ten percent.

Keywords: Return on Asset (ROA), Return on Equity (ROE), Net Profit Margin (NPM), Price to Book Value (PBV)

Penelitian ini bertujuan untuk mengetahui pengaruh Net Profit Margin, Return On Equity dan Return On Asset terhadap Price to Book Value. Penelitian ini menggunakan data sekunder yang diperoleh dari laporan keuangan perbankan yang diperoleh dari Indonesian Capital Market Directory (ICMD). Jumlah sampel penelitian secara keseluruhan ada 19 bank. Hasil penelitian menemukan bahwa NPM dan ROE tidak berpengaruh signifikan terhadap PBV. Sedangkan ROA berpengaruh positif terhadap PBV. Kontribusi seluruh variabel tergolong sedang, seluruh variabel independen hanya mampu memberikan pengaruh terhadap PBV sebesar sepuluh persen.

Kata kunci: Return on Asset (ROA), Return on Equity (ROE), Net Profit Margin (NPM), Price to Book Value (PBV)
\end{abstract}

\section{PENDAHULUAN}

Kejadian krisis global yang terjadi pada tahun 2008 tepatnya awal bulan Oktober yang melanda hampir seluruh dunia, termasuk di Indonesia khususnya pada sektor perbankan, harga saham perbankan mengalami penurunan pada perdagangan di lantai Bursa Efek Indonesia. Akibatnya berdampak likuiditas perbankan yang semakin sulit. Salah satu dampak krisis global tahun 2008 di Indonesia adalah kasus PT Bank Century yang sempat mengalami kesulitan likuiditas karena mengalami kekalahan kliring akibat adanya penarikan dana besar yang dilakukan nasabah potensial. Kalah kliring yang menimbulkan antrian panjang nasabah yang kesulitan mencairkan uangnya ini juga tersiar ke publik hingga menimbulkan negative signalment.

Rasio price to book value (PBV) berfungsi untuk melengkapi analisis book val- ue. Jika pada analisis book value investor hanya mengetahui kapasitas per lembar dari nilai saham, pada ratio PBV investor dapat membandingkan langsung book value dari suatu saham dengan market valuenya. Nilai rasio PBV ini dapat memberikan informasi kepada investor, sehingga investor dapat mengetahui langsung sudah berapa kali market value suatu saham dihargai dari book value-nya.

Setelah mendapatkan rasio PBV, investor dapat membandingkan langsung rasio ini dengan saham-saham di industrinya atau yang bergerak disektor ekonomi yang sama. Dengan demikian investor akan mendapat gambaran mengenai harga suatu saham, apakah market value saham tersebut sudah relatif mahal atau ternyata masih murah. Memang tidak ada ukuran pasti mahal tidaknya suatu harga saham jika diukur dari rasio PBV-nya kare- 
na hal ini sangat tergantung pada ekspektasi dan kinerja dari perusahaan/ saham tersebut. Tapi, paling tidak memberikan gambaran potensi pergerakan harga suatu saham. Maksudnya adalah jika suatu saham yang berkinerja baik ternyata PBV-nya masih rendah dibandingkan ratarata PBV saham di sektornya, harga saham tersebut masih memiliki potensi untuk naik, demikian pula sebaliknya.

Penelitian yang dilakukan oleh Rosenberg et al. (1985) menemukan bahwa saham-saham yang memiliki PBV yang rendah akan menghasilkan return yang secara signifikan lebih tinggi daripada saham-saham yang memiliki rasio PBV yang tinggi. Investor dapat mempertimbangkan rasio PBV untuk membedakan saham mana yang harganya wajar, terlalu tinggi (overvalued), atau terlalu rendah (undervalued).

Penelitian tentang pengaruh return on asset (ROA) terhadap PBV telah dilakukan oleh Sparta (2000), Marpaung (2004), Putra (2007), Wirawati (2008). Penelitian Sparta (2000) menemukan bahwa ROA berpengaruh positif dan signifikan terhadap PBV, begitu pula hasil yang ditemukan oleh Marpaung (2004) dan Wirawati (2008) yang menemukan pengaruh yang positif dan signifikan untuk variabel ROA terhadap PBV. Tetapi hasil berbeda di temukan oleh Putra (2007) dalam penelitiannya, dimana Putra menemukan bahwa ROA tidak berpengaruh signifikan terhadap PBV. Penelitian yang dilakukan oleh Putra menunjukan bahwa perubahan ROA tidak mempengaruhi PBV.

Penelitian tentang pengaruh return on equity (ROE) terhadap PBV telah dilakukan oleh Wirawati (2008), Hidayati (2010), dan Dendy (2011). Dalam penelitiannya, Wirawati menemukan bahwa ROE berpengaruh positif dan signifikan terhadap PBV, hal serupa juga ditemukan oleh Hidayati (2010) yang juga menemukan pengaruh yang positif dan signifikan antara ROE dengan PBV. Hal berbeda ditemukan oleh Dendy (2011), hasil penelitian yang dilakukan oleh Dendy (2011) menemukan bahwa ROE berpengaruh positif namun tidak signifikan terhadap PBV. Ditemukannya hasil yang berbeda antara penelitian yang dilakukan oleh Wirawati, Hidayati dengan penelitian yang dilakukan oleh Dendy (2011) menggambarkan bahwa terjadi gap penelitian dimana ketika penelitian dilakukan pada tahun 2008 dan 2010 hasil penelitian menunjukan bahwa ROE memiliki pengaruh positif dan signifikan terhadap PBV sedangan penelitian yang dilakukan oleh Dendy di tahun 2011 menemukan bahwa ROE tidak berpengaruh signifikan terhadap PBV. Dimana dari penelitian yang dilakukan oleh Dendy (2011) disimpulkan bahwa perubahan yang terjadi pada ROE tidak akan mempengaruhi PBV secara signifikan.

Berdasarkan penjelasan tersebut, tujuan dari penelitian ini adalah untuk mengetahui pengaruh net profit margin, return on equity dan return on asset terhadap price to book value.

\section{METODE PENELITIAN}

Obyek penelitian ini adalah industri perbankan yang terdaftar dalam Bursa Efek Indonesia. Populasi dalam penelitian ini adalah seluruh perusahaan perbankan yang terdaftar di Bursa Efek Indonesia yang berjumlah 31 perbankan. Metode pengambilan sampel yang digunakan adalah metode purposive sampling. Sehingga masingmasing perusahaan dalam populasi tidak memiliki kesempatan yang sama untuk menjadi sampel, kecuali perusahaan yang memenuhi seluruh kriteria penelitian. Sampel yang digunakan dalam penelitian ini adalah sebanyak 19 Bank dari 31 Bank disebabkan 12 Bank lainnya tidak memenuhi kriteria persyaratan sebagai sampel penelitian. Model analisis data yang di gunakan dalam penelitian ini adalah Analisis Regresi Linear Berganda.

\section{ANALISIS DAN PEMBAHASAN}

Penelitian ini menjelaskan mengenai variabel net profit margin (NPM), return on assets (ROA), dan return on equity (ROE) yang mempengaruhi price to book value (PBV) pada industri perbankan di Indonesia baik secara bersama-sama maupun secara parsial.

NPM memiliki hubungan yang erat terhadap PBV dimana NPM menunjukan kemampuan perusahaan memperoleh 
penghasilan terhadap penjualan. Dengan margin laba bersih yang tinggi maka tingkat kepercayaan investor akan meningkat, hal tersebut akan berdampak pada PBV yang meningkat pula. ROA menunjukkan kemampuan perusahaan dalam menghasilkan laba dengan memanfaatkan total aset yang dimiliki perusahaan. Dengan laba yang tinggi maka tingkat kepercayaan investor akan meningkat, hal tersebut berdampak pada PBV yang meningkat.

Variabel lainnya yang memiliki hubungan dengan PBV adalah ROE. Adanya pertumbuhan ROE menunjukkan prospek perusahaan yang semakin baik karena berarti adanya potensi peningkatan keuntungan yang diperoleh perusahaan sehingga akan meningkatkan kepercayaan investor serta akan mempermudah manajemen perusahaan untuk menarik modal dalam bentuk saham. Apabila terdapat kenaikkan permintaan saham suatu perusahaan, maka secara tidak langsung akan menaikkan harga saham tersebut di pasar modal.

NPM, ROA, ROE dan PBV memiliki hubungan yang erat di dalam industri perbankan dimana NPM merupakan rasio antara laba bersih setelah pajak dengan penjualanyang mengukur laba bersih yang dihasilkan dari setiap rupiah penjualan. Dalam industri perbankan profit margin digunakan untuk menghitung sejauh mana kemampuan perusahaan menghasilkan laba bersih pada tingkat penjualan tertentu. ROA yang rendah mengindikasikan pendapatan perusahaan yang rendahterhadap sejumlah aset yang dimilikinya. Jadi, ROA yang rendah jika dibandingkan ratarataindustrinya menunjukan bahwa adanya penggunaan asset perusahaan yang tidak efisien, sedangkan perusahaan perbankan dengan ROA tinggi akan menarik minat para investor untuk menanamkanmodalnya pada perusahaan tersebut.

ROE yang tinggi menandakan kemampuan perusahaan laba yang tersedia bagi pemegang saham perusahaan. Rasio ini merupakan ukuran profitabilitas dari sudut pandang pemegang saham untuk berinvestasi pada industri perbankan. Tetapi pada rasio ini terdapat satu kelemahan, yaitu tidak memperhitungkan adanya deviden maupun capital gain untuk pemegang saham.

Berdasarkan hasil analisis pengaruh variabel NPM, ROA, dan ROE terhadap PBV pada Industri perbankan di Indonesia dengan menggunakan analisis regresi linear berganda diketahui bahwa secara bersama - sama (simultan) variabel bebas NPM, ROA, dan ROE berpengaruh terhadap PBV. Dimana $\mathrm{F}_{\text {hitung }}=4,208>\mathrm{F}_{\text {tabel }}=2,69$. Besarnya kontribusi variabel bebas NPM, ROA, ROE terhadap variabel tak bebas PBV dapat dilihat pada nilai $\mathrm{R}$ determinasinya yakni sebesar $=0,321$ artinya konstribusi variabel bebas terhadap variabel terikat adalah $32,1 \%$.

Hasil penelitian ini mendukung penelitian yang dilakukan oleh Sparta (2000), Marpaung (2004), Wirawati (2008), yang juga menemukan bahwa secara bersama - sama variabel bebas yang meliputi NPM, ROA, ROE berpengaruh terhadap PBV.

Hasil penelitian ini memberikan makna bagi industri perbankan di Indonesia hendaknya memperhatikan variabel NPM, ROA, ROE. Karena pertumbuhan ketiga variabel bebas tersebut bisa ditangkap oleh para investor sebagai sinyal positif dari perbankan sehingga akan meningkatkan kepercayaan investor serta akan mempermudah manajemen perusahaan untuk menarik modal baik dalam bentuk saham maupun dalam bentuk lainnya.

\section{ANALISIS DAN PEMBAHASAN}

\section{Net Profit Margin dan Price to Book Value}

Net Profit Margin (NPM) mengukur seberapa besar keuntungan bersih perusahaan dari setiap penjualan yang dilakukan. Net income dari perusahaan, merupakan keuntungan yang siap dibagikan menjadi dividen dan laba yang di tahan. Pembagian dividen berkaitan dengan investor yang akan menanamkan dananya di perusahaan, karena keuntungan dari melakukan kegiatan di pasar modal salah satunya adalah investor memperoleh dividen dari perusahaan. Sedangkan laba yang ditahan mengisyaratkan kegiatan perusahaan yang terus berkembang, karena laba yang ditahan nantinya akan di gunakan untuk melakukan pengembangan perusahaan. Oleh karena 
itu, nilai NPM yang tinggi akan mengindikasikan keuntungan perusahaan yang tinggi pula dan kegiatan perusahaan yang berkembang (Helfert, 1994).

Nilai rata-rata pertumbuhan NPM perbankan dari tahun 2006 ke tahun 2007 mengalami peningkatan yakni dari 0,82 satuan meningkat menjadi 1,05 satuan dimana terjadi peningkatan sebesar 0,23 satuan, peningkatan ini terjadi disebabkan karena secara umum perbankan mampu meningkatkan jumlah penjualan dan mampu menekan beban penjualan, perbankan juga mampu meningkatkan laba bersih sehingga pembagian dividen akan semakin besar yang pada akhirnya mampu menjadi daya tarik bagi investor.

Di tahun 2008 rata-rata NPM perbankan di Indonesia mengalami penurunan drastis menjadi 0,11 satuan hal ini disebabkan secara umum perbankan kewalahan mengatasi beban penjualan sehingga beban penjualan yang ditanggung bank sangat tinggi. Di tahun 2009 rata-rata NPM bank tetap tidak mengalai perubahan, di tahun 2010 rata-rata NPM baru mengalami peningkatan menjadi 0,17 satuan di tahun 2010 ini bank mulai kembali mencoba menekan beban penjualan agar mampu meningkatkan penjualan dan memperoleh laba bersih yang tinggi sehingga rata-rata NPM bank mengalami peningkatan dari 0,11 satuan meningkat menjadi 0,17 satuan dan di tahun 2012 rata-rata NPM bank kembali mengalami peningkatan menjadi 0,49 satuan, di tahun 2011 secara umum bankbank yang ada di Indonesia telah kembali mampu meningkatkan penjualan mereka sehingga mereka mampu memperoleh laba bersih yang besar. Hasil penelitian yang telah dilakukan menunjukan bahwa nilai $\mathrm{t}_{\text {hitung }}$ untuk variabel NPM lebih kecil dibandingkan nilai $t_{\text {tabel }}$ NPM. Sehingga dapat ditarik sebuah kesimpulan bahwa NPM tidak berpengaruh signifikan terhadap PBV. Hasil penelitian ini mendukung hasil penelitian yang dilakukan oleh Maylizza (2009), dimana penelitian yang dilakukan oleh Maylizza di tahun 2009 menemukan bahwa NPM tidak berpengaruh signifikan terhadap PBV.

Hasil penelitian ini juga tidak mendukung teori dari Horne dan Wachowicz
(2005) yang menyatakan bahwa NPM yang tinggi akan menunjukan kekuatan bisnis dan juga semangat yang kuat dari pihak manajemen untuk melakukan kontrol biaya. Dengan demikian perusahaan tersebut akan memiliki efisiensi yang tinggi dan juga menunjukan kemampuan perusahaan untuk menghasilkan laba yang tinggi dari penjualannya. Sehingga jika dikaitkan dengan PBV, dimana jika perusahaan mampu menghasilkan laba yang tinggi dari penjualannya maka tingkat harga sahamnya juga akan meningkat, semakin tinggi rasio ini berarti pasar percaya akan prospek perusahaan. Tingkat kepercayaan pasar yang tinggi pada perusahaan maka akan mengakibatkan harga saham perusahaan tersebut akan meningkat pula. Sehingga jika dilihat dari teori maka seharusnya terdapat pengaruh antara NPM dengan PBV tetapi hasil berbeda ditemukan dari penelitian ini dimana variabel NPM tidak berpengaruh terhadap PBV. Tidak berpengaruhnya NPM terhadap PBV disebabkan oleh nilai NPM yang berada di bawah 01 yakni $-0,11$ yang jauh dari 0 dan 1 , sehingga biaya yang dikeluarkan perusahaan tidak efisien biaya yang dikeluarkan dan juga semakin kecilnya tingkat kembalian keuntungan bersih yang diperoleh perusahaan.

\section{Return on Assets dan Price to Book Value}

Return on assets merupakan rasio yang mengukur kemampuan manajemen bank mengelola keseluruhan asetnya dalam memperoleh laba. Return on asset menunjukkan kemampuan perusahaan dalam menghasilkan laba dengan memanfaatkan total aset yang dimiliki perusahaan. Dengan laba yang tingg makatingkat kepercayaan investor akan meningkat, hal tersebut berdampak pada price to book value yang meningkat.

Perkembangan ROA perbankan d Indonesia dari periode 2006 sampai 2011 dapat di katakan berfluktuasi dimana nilai rata-rata ROA di tahu 2006 sampai 2007 mengalami penurunan yakni dari 1,30 satuan menurun di tahun 2007 menjadi 1,27 satuan, hal ini disebabkan oleh penjualan yang mengalami penurunan, biaya-biaya 
yang meningkat serta bank tidak mampu mengurai aktiva sehingga rata-rata ROA di tahun 2007 lebih rendah di bandingkan 2006. Demikian pula di tahun 2008 hingga 2009 rata-rata ROA yang diperoleh masih lebih rendah di bandingkan rata-rata di tahun 2007.

Di tahun 2010 rata-rata ROA bank di Indonesia mengalami peningkatan menjadi 1,63 satuan hal ini disebabkan karena di tahun 2010 bank di Indonesia secara umum mampu meningkatkan penjualan, mengurangi biaya serta mampu mengurai aktiva. Peningkatan rata-rata ROA juga kembali terjadi di tahun 2011 dimana ratarata ROA di tahun 2011 menjadi 2,40 satuan.

Pengaruh ROA terhadap PBV pada industri perbankan di Indonesia dapat dilihat pada nilai $t_{\text {hitung }}$ untuk variabel ROA yang lebih besar dibandingkan nilai $t_{\text {tabel }}$ dari NPM. Dengan lebih besarnya nilai $t_{\text {hitung }}$ dibandingkan nilai $t_{\text {tabel }}$ maka dapat ditarik sebuah kesimpulan bahwa variabel bebas ROA berpengaruh positif dan signifikan terhadap variabel terikat PBV.

Hasil penelitian ini mendukung teori yang diutarakan oleh Ang (1997), ROA menunjukkan kemampuan perusahaan dalam menghasilkan laba dengan memanfaatkan total aset yang dimiliki perusahaan. Dengan laba yang tinggi maka tingkat kepercayaan investor akan meningkat, hal tersebut berdampak pada PBV yang meningkat.

Hasil penelitian ini mendukung penelitian yang dilakukan oleh Sparta (2000) yang menemukan pengaruh positif dan signifikan variabel ROA terhadap Variabel PBV, dan penelitian yang dilakukan Marpaung (2004) yang juga menemukan ROA berpengaruh positif dan signifikan terhadap PBV, dan Wirawati (2008) yang menemukan ROA berpengaruh positif dan signifikan terhadap PBV.

Hasil penelitian ini tidak mendukung penelitian yang dilakukan oleh Putra (2007) yang melakukan penelitian tentang pengaruh kinerja keuangan dan beta saham terhadap PBV, dimana dalam penelitiannya Putra (2007) menemukan hasil yang berbeda dengan hasil yang diperoleh dalam penelitian yang peneliti lakukan. Putra (2007) menemukan bahwa ROA berpengaruh tidak signifikan terhadap PBV.

ROA yang meningkat akan berpengaruh terhadap meningkatnya PBV sebab dengan tingkat keuntungan yang tinggi maka akan meningkatkan tingkat kepercayaan investor dan hal tersebut akan mengakibatkan PBV menjadi meningkat pula. Begitu pula sebaliknya jika kemampuan perusahaan dalam menghasilkan laba dengan memanfaatkan total aset yang dimiliki perusahaan mengalami penurunan maka akan mengakibatkan menurunya kepercayaan investor dan akan berdampak terhadap PBV yang juga akan mengalami penurunan.

\section{Return on Equity dan Price to Book Value}

Return on Equity merupakan salah satu analisis rasio untuk mengukur tingkat profitabilitas yang dimiliki suatu perusahaan. Rasio ini memperlihatkan sejauh mana suatu perusahaan dapat mengelola modal sendiri (net worth) secara efektif serta mengukur tingkat keuntungan yang akan diperoleh dari investasi yang telah dilakukan pemilik modal sendiri, selain itu pula rasio ini dapat mengukur sejauh mana kemampuan perusahaan dalam memberikan keuntungan bagi pemegang saham biasa (pemilik modal) dengan menunjukan persentase laba bersih yang tersedia untuk modal pemegang saham yang telah digunakan perusahaan.

Nilai laba bersih yang digunakan umumnya adalah nilai laba bersih yang diperoleh perusahaan selama melakukan usahanya sedangkan nilai modal sendiri yang digunakan adalah nilai modal sendiri yang digunakan sampai akhir periode untuk melakukan usahanya tersebut. Return On Equity juga merupakan suatu pengukuran dari penghasilan (income) yang tersedia bagi para pemilik perusahaan (baik pemegang saham biasa maupun pemegang saham preferen) atas modal yang mereka investasikan di dalam perusahaan. Secara umum tentu saja semakin tinggi return atau penghasilan yang diperoleh maka semakin baik pula kedudukan pemilik perusahaan. 
Return on equity merupakan salah satu cara untuk menghitung efisiensi perusahaan dengan membandingkan antara laba yang tersedia bagi pemilik modal sendiri dengan jumlah modal sendiri yang menghasilkan laba tersebut. Atau dengan kata lain, yaitu kemampuan perusahaan dengan modal sendiri yang bekerja didalamnya untuk menghasilkan keuntungan, laba yang diperhitungkan adalah laba usaha setelah dikurangi dengan bunga dan pajak (earning after tax income). Sedangkan modal yang diperhitungkan hanyalah modal kerja (equity) yang bekerja dalam suatu perusahaan.

Perkembangan rata-rata ROE di tahun 2006 adalah sebesar 10,01 dan meningkat di tahun 2007 menjadi 10,52 peningkatan ini terjadi disebabkan di tahun 2007 perbankan secara umum mampu meningkatkan nilai profit marginya dan mampu meningkatkan nilai leverage pada tingkatan tertentu yang mampu meningkatkan ROE. Penurunan ROE terjadi di tahun 2008 hal ini disebabkan oleh bank secara umum yang tidak mampu meningkat profit marginnya. Di tahun 2009 bank di Indonesia mampu meningkatkan kembali rata - rata ROE menjadi 10,48 satuan dan di tahun 2010 kembali meningkat menjadi 12,23 satuan dan di tahun 2012 meningkat menjadi 13,21 satuan.

Pengaruh ROE terhadap PBV pada industri perbankan di Indonesia dapat dilihat pada nilai $t_{\text {hitung }}$ untuk variabel ROE lebih kecil dari nilai $t_{\text {tabel }}$. Dengan lebih besarnya nilai $t_{\text {tabel }}$ dibandingkan nilai $t_{\text {hitung }}$ maka dapat ditarik sebuah kesimpulan bahwa variabel bebas ROE tidak berpengaruh terhadap variabel terikat PBV.

Hal ini tidak mendukung teori yang diutarakan oleh Irawan (1996), yang menyatakan bahwa pertumbuhan ROE menunjukan prospek perusahaan yang semakin baik karena menunjukan adanya potensi peningkatan keuntungan yang diperoleh perusahaan. Hal ini akan ditangkap oleh investor sebagai sinyal positif dari perusahaan dan meningkatkan kepercayaan investor serta akan mempermudah manajemen perusahaan untuk menarik modal dalam bentuk saham. Apabila terdapat kenaikan permintaan saham suatu perus- ahaan, maka secara tidak langsung akan menaikan harga saham di pasar modal. Dan hal ini berkaitan dengan PBV, dimana PBV dapat digunakan untuk mengukur tingkat kemahalan dari suatu saham.

Hasil penelitian ini tidak mendukung penelitian yang dilakukan oleh Wirawati (2008), Hidayati (2010) yang di dalam penelitian menemukan hasil yang berbeda tentang pengaruh ROE terhadap PBV, dimana didalam penelitian yang mereka lakukan mereka menemukan hasil penelitian bahwa variabel ROE berpengaruh positif dan signifikan terhadap variabel PBV. Dimana hasil ini berbeda dengan hasil penelitian yang peneliti temukan dimana hasil temuan peneliti tidak melihat adanya pengaruh variabel ROE terhadap variabel PBV.

Hasil penelitian yang dilakukan Dendy (2011) agak berbeda dengan hasil penelitian yang dilakukan oleh peneliti lakukan dan juga Wirawati (2008), Hidayati (2010), dimana dalam penelitiannya Dendy (2011) menemukan ada pengaruh positif variabel ROE terhadap PBV namun tidak signifikan.

\section{SIMPULAN}

Berdasarkan hasil analisis penelitian dan pembahasan tentang pengaruh net profit margin (NPM), return on asset (ROA), return on equity (ROE) terhadap price to book value (PBV) pada industri perbankan di Indonesia maka dapat ditarik kesimpulan bahwa rendahnya nilai net profit margin (NPM) dari hasil penelitian menunjukkan lemahnya kekuatan bisnis dan juga semangat dari pihak manajemen untuk melakukan kontrol biaya. Hal ini menyebabkan yang di keluarkan bank tidak efisien dan juga menunjukkan semakin kecilnya tingkat pengembalian keuntungan bersih yang diperoleh bank. Selain itu, tingginya nilai return on asset (ROA) dari hasil penelitian menunjukkan bahwa, bank mampu untuk menghasilkan laba dengan memanfaatkan total aset yang dimiliki, sehingga hal ini akan meningkat kepercayaan investor sehingga mengakibatkan PBV menjadi meningkat pula. Rendahnya nilai return on equity (ROE) dari hasil penelitian 
yang diperoleh juga menunjukkan kurang baiknya prospek bank dalam meningkatkan kepercayaan investor. Hal tersebut akan mempersulit manajemen Bank untuk menarik modal dalam bentuk saham.

\section{SARAN}

Industri perbankan di Indonesia hendaknya memperhatikan dan menciptakan pertumbuhan ROA untuk terus meningkat. Sebab pertumbuhan ROA yang meningkat atau tinggi akan berpengaruh positif terhadap perkembangan PBV pada perusahaan. Dimana jika PBV tinggi maka pasar akan semakin percaya terhadap prospek perusahaan perbankan tersebut dan hal tersebut akan menimbulkan harga saham perbankan tersebut meningkat pula.

\section{DAFTAR PUSTAKA}

Ang, R.1997. Buku Pintar: Pasar Modal Indonesia. Jakarta: Mediasoft Indonesia.

Dendy, A. S. 2011. Pengaruh Return On Equity (ROE) dan Deviden Payout Ratio (DPR) terhadap Price to Book Value (PBV) pada Perusahaan Perbankan yang Go Publik di PT. Bursa Efek Indonesia. Skripsi, Universitas Pembangunan Nasional Veteran, Surabaya.

Helfert, E. A. 1996. Teknik Analisis Keuangan. Jakarta: Erlangga.

Hidayati, E. E. 2010. Analisis pengaruh DER, DPR, ROE dan Size terhadap PBV perusahaan manufaktur yang listing di BEI periode 2005-2007. Tesis, Universitas Diponegoro, Semarang.

Horne, J. C. V dan J. M. Wachowicz. 2005. Prinsip - prinsip manajemen keuangan. 12ed. Jakarta: Salemba Empat.
Irawan, R. A. C. 1996. IPO sebagai Alternatif Sumber Pendanaan bagi Perusahaan. Usahawan, 25 (4).

Marpaung, H. 2004. Analisis Pengaruh Return on Assets, Dividend Payout Ratio, Debt Equity Ratio dan Economic Value Added terhadap Price Book Value pada Perusahaan Manufaktur di Bursa Efek Jakarta. Jurnal Riset Akutansi Indonesia, 1 (1): 127-140.

Maylizza, D. 2009. Pengaruh Net Profit Margin, Total Asset Turnover, dan Leverage Ratio terhadap Price to Book Value Ratio (Studi pada Perusahaan Asuransi yang Terdaftar di Bursa Efek Indonesia Periode 2004-2007). Skripsi, Universitas Airlangga, Surabaya.

Putra, T. P. et al. 2007. Pengaruh Kinerja Keuangan Dan Beta Saham Terhadap Price To Book Value (Studi pada Perusahaan Real Estate dan Property yang Listed di Bursa Efek Indonesia Periode Tahun 2004-2006). Jurnal Studi Manajemen dan Organisasi, 4 (2): 81-90.

Rosenberg, B., K. Reid, dan R. Lanstein. 1985. Persuasive Evidence of Market Inefficiency. Journal of PortofolioManajement, 11 (3): 9-17.

Sparta. 2000. Pengaruh Faktor-faktor Fundamental Lembaga Keuangan Bank terhadap Harga Sahamnya di Bursa Efek Indonesia. Jurnal Akuntansi FE Untar, 4 (1).

Wirawati, N. G. P. 2008. Pengaruh Faktor Fundamental Perusahaan terhadap Price to Book Value dalam Penilaian Saham di Bursa Efek Jakarta dalam Kondisi Krisis Moneter. Media Riset Akuntansi, Auditing dan Informasi, 3 (1): 1-23. 
